\title{
PROBLEM POWSZECHNIKÓW W UJĘCIU PSYCHOLOGICZNYM U JANA BURYDANA
}

Artykuł wybitnego mediewisty polskiego jest wyjątkiem z obszernej monografii o Janie Burydanie. Trzy pierwsze rozdziały tej monografii przedstawił autor jako rozprawę habilitacyjną na Wydziale Teologicznym UJ w Krakowie w r. 1917. Krótkie jej streszczenie ukazało się drukiem w 1916 r. Monografia, jako całość, nie była dotychczas publikowana i uchodziła za zaginioną. Odnaleziona w lipcu 1987 r. w archiwum misjonarzy domu stradomskiego w Krakowie, może obecnie się ukazać przynajmniej częściami. Rozdział szósty monografii, obejmujący poglądy etyczne Burydana, oddano do druku w „Studiach Mediewistycznych” (XXVI, I, 1988). Być może, niektóre rozdziały lub paragrafy rozprawy ukażą się z uzupełnieniami, biorąc pod uwagę siedemdziesięcioletni okres od jej opracowania.

Artykuł, o którym mowa, tworzy pierwszy paragraf trzeciego rozdziału monografii, zajmującego się zagadnieniem powszechników. Zagadnienie to rozpatruje autor $\mathrm{z}$ trojakiego punktu widzenia: psychologicznego, metafizycznego i teoriopoznawczego. Podobnie jak w innych swych rozprawach, autor zestawia i tutaj myśl wieków średnich z poglądami wspólczesnymi. Dzisiejsza mediewistyka niechętnie spogląda na tego rodzaju tendencję; tendencja ta jednak nadaje refleksjom Konstantego Michalskiego swoisty koloryt oraz akcentuje ciągłość i jedność doświadczenia filozoficznego.

W ostatnich dziesięcioleciach ukazało się sporo wydań krytycznych dzieł Burydana. Maria E. Reina wydała traktat De suppositionibus (1957), V. Zoubov opublikował Quaestio de puncto (1959), H. Hubien — traktat De consequentiis (1976), T. K. Scott - Sofizmaty (1977), J. Schneider - Quaestiones do Kategorii Arystotelesa (1983), Ria van der Lecq - Quaestiones longae do Hermeneutyki Arystotelesa (1983), R. Tatarzyński - komentarz do Isagogi Porfiriusza (1986). Ukazały się też w ostatnich latach nowe opracowania filozofii Burydana. Dla przykładu wymieńmy tylko fundamentalne dzieło M. Markowskiego o burydanizmie w Polsce w okresie przedkopernikańskim (1971) oraz rozprawę J. B. Korolca o filozofii moralnej Burydana (1973). Oczywiście, dla poznania myśli Burydana ważne są także inne pozycje bibliograficzne, dotyczące zwłaszcza filozofii XIV w. Dokładny przegląd tych pozycji daje nam synteza filozofii wieków średnich K. Flascha (1986).

Chociaż ukazaly się nowsze prace o Burydanie, wzbogacające naszą wiedzę o nim i o jego filozofii, to jednak rozprawa K. Michalskiego nie straciła na swej wartości. Wykorzystanie rękopisów średniowiecznych, uwzględnienie szerokiego tla ideowego, oryginalne ujęcie tematu, zwięzła a zarazem piękna proza naukowa autora - stanowią do dziś pewnego rodzaju wzór dla badań mediewistycznych. Klasyk i pionier mediewistyki, jak u nas slusznie napisano o ks. Konstantym Michalskim (Zdzisław Kuksewicz, Mieczysław Markowski), może być w dalszym ciągu nauczycielem, w tym znaczeniu, w jakim wieki średnie mówiły o nauczycielu-mistrzu. Dobrze rozwijająca się szkoła mediewistyczna w Polsce, jak można sądzić, nie ma co do tego wątpliwości. A i mediewiści zagraniczni, zwłaszcza z ośrodka w Bochum, (np. Olaf Pluta, 1986) skłaniają się do tej opinii.

Ks. Aleksander Usowicz 


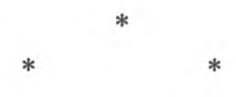

Krytyka poznania sprowadza się w filozofii scholastycznej w znacznej mierze do zagadnienia wartości pojęć ogólnych. Rozwój tego zagadnienia w średniowieczu rozpatrywano dotąd pod dwoma kątami widzenia: jeden był systematyczny, drugi genetyczny. Systematycy ${ }^{1}$ starali się wszelkie zapatrywania średniowieczne na pojęcia ogólne zamknąć w pewnych sztywnych ramach, w pewnym schemacie, twierdząc, że każdy pogląd na ogół można z pewnością zaliczyć albo do realizmu przesadnego, albo do realizmu umiarkowanego, albo do konceptualizmu, albo wreszcie do nominalizmu. Genetyczny punkt widzenia wystąpił najsilniej w pracach J. Reinersa ${ }^{2}$, który średniowieczne prądy teorio-poznawcze wyprowadza z dwóch źródeł: z pierwiastków perypatetyczno-boecjańskich miał się zrodzić nominalizm i realizm umiarkowany, z myśli platońskiej i neoplatońskiej realizm przesadny ${ }^{3}$.

Dla historyka filozofii najważniejszy jest niezawodnie punkt genetyczny, bo nie można nigdy żadnego filozofa, ani żadnej jego myśli, wyrywać gwałtownie $\mathrm{z}$ tego żywego tła, z którego wyrastają. $\mathrm{Z}$ tym wszystkim w analizie problemu filozoficznego nie tylko należy uwzględnić jego związki z przeszłością i wpływy na dalszy rozwój idei, ale trzeba także uwydatnić wszystkie jego strony, bo tylko w ten sposób otrzymamy pełne jego oświetlenie. Dzisiaj w analizie filozoficznej zaczyna się coraz bardziej i coraz ściślej rozróżniać elementy psychologiczne, metafizyczne i logiczne czy teoriopoznawcze, a skrupulatne oddzielanie tych pierwiastków w rozbiorze myśli średniowiecznego autora z pewnością nie sfałszuje ostatecznej syntezy, lecz nada jej liniom należytą wyrazistość i dokładność.

Badając więc zapatrywania Burydana na problem pojęć ogólnych, będziemy w nich kolejno uwzględniali ich stronę psychologiczną, metafizyczną i teoriopoznawczą. Aczkolwiek trzy te strony najczęściej się ze sobą zespalają, to przecież raz jedna, drugi raz inna $z$ nich przeważa i na pierwszy wysuwa się plan, łącząc się z pewnym tradycyjnym sposobem traktowania problemu. Każdą $\mathrm{z}$ tych stron $\mathrm{z}$ osobna uwidocznimy w pismach Burydana, osadzając ją na ogólniejszym tle literatury średniowiecznej, bo przez to wystąpi wyraziściej perspektywa dziejowa, uwydatnią się własne i obce, skądinąd przejęte pierwiastki w myśli naszego filozofa.

Moment psychologiczny występuje bardzo silnie obok strony teoriopozna-

${ }^{1}$ M. de Wulf, Geschichte der mittelalterlichen Philosophie. Deutsche Übersetzung von Dr. R. Eisler, Tübingen 1913, s. 124.

2 J. R e in e rs, Der aristotelische Realismus in der Frühscholastik, I. D., Bonn 1907. Der Nominalismus in der Frühscholastik, [w:] Beiträge zur Geschichte der Philosophie des Mittelalters, Bd. 8, H. 5, 1910.

${ }^{3}$ Der Nominalismus, s. 4. 
wczej we wszelkich rozważaniach problemu pojęć ogólnych, jakie zachodzą w literaturze terministycznej, związanej historycznie i rzeczowo z gramatyką spekulatywną. Już gdzie indziej wykazałem ${ }^{4}$, że logikę terministyczną należy badać w związku ze średniowieczną gramatyką spekulatywną, bo obydwie pochodzą z tego samego źródła, z Arystotelesowego traktatu De interpretatione i odnośnego komentarza Boecjusza, obydwie równolegle do siebie się rozwijają prawdopodobnie nie bez wpływów dawnej tradycji stoickiej, obie wreszcie nawzajem na siebie oddziałują.

Różnią się gramatyka spekulatywna i logika terministyczna między sobą przez to, że każda z nich ma osobny przedmiot badania. Elementem najprostszym, jakim według Tomasza z Erfurtu zajmuje się gramatyka, jest część mowy, pars orationis, elementem zaś najprostszym, jaki bada logika, jest wyraz, terminus ${ }^{5}$. Część mowy i terminus łączą się ze sobą przez prostsze, rodzajowe pojęcie znaku symbolicznego, signum rerum. Na symbol ten, signum rerum składają się: 1) dostępny dla zmysłów fakt, którym jest zazwyczaj głos, vox, oraz 2) przydzielona mu przez osobny akt intencjonalny funkcja oznaczania, significatio ${ }^{6}$. Każdy symbol słowny nie tylko oznacza pewną rzecz w ogóle, lecz także oznacza ją w ściśle określony sposób; inaczej tę samą rzeczywistość oznacza rzeczownik, inaczej słowo, inaczej przymiotniki, inaczej wreszcie jakakolwiek inna część mowy. Rzeczownik „dolor” np. oznacza pewien stan uczuciowy, ujmując go jako coś stałego; za to słowo „doleo" wskazuje na ten sam nastrój, ale ujmuje go z jego strony zmiennej, dynamicznej ${ }^{7}$. Wobec tego należy przyjąć, że każda część mowy, obok wspólnej jej z innymi funkcjami oznaczania, significatio, spełnia nadto drugą, sobie tylko właściwą funkcję oznaczania rzeczy z pewnej jej strony, consignificatio: różne wyrazy na ten sam wskazują przedmiot, ale $\mathrm{w}$ różny sposób, przedstawiają go $\mathrm{z}$ różnego punktu widzenia. Ta druga, specyficzna funkcja oznaczania rzeczy przez wyrazy w sposób swoisty i ściśle określony, nazywa się w słowniku średniowiecznych gramatyków

${ }^{4}$ Zob. moją rozprawę pt. Michat z Bystrzykowa i Jan ze Stobnicy jako przedstawiciele skotyzmu w Polsce, [w:] Archiwum Komisji do badania historii filozofii w Polsce, t. 1 cz. 1, Kraków 1915, 25-32.

5 „Pars orationis est dictio, ut habet modum significandi activum. Terminus vero dicit rationem terminandi resolutiones syllogismi, quia dialecticus resolvit syllogismum in propositiones, et propositiones in subiectum et praedicatum, quae dicuntur termini secundum logicum" (Joannes D u n s S cot u s, Grammaticae speculativae nova editio cura M. Fernandez Garcia, Ad Claras Aquas 1902, s. 20). Tekst ten jest przypisywany Szkotowi.

6 „Dicitur signum per rationem signandi vel repraesentandi aliquid absolute; sed dicitur dictio formaliter per rationem signandi voci superadditum" (tamże).

„Cum intellectus vocem ad significandum et consignificandum imponit, duplicem ei rationem tribuit" (tamże, s. 11).

${ }^{7}$ "Les deux groupes de sons (voces) que forment dolor, doleo, signifient la même chose (res), mais avec des manières d'etre (modi essendi) ou propriétés différentes. Dolor là signifie en tant que permanente (per modum permanentis), doleo en tant que s'écoulant (per modum fluxus). La permanance et l'écoulement sont des propriétés de la chose que signifie dolor et doleo" (Ch. Th u rot, De l'organisation de l'enseignement dans l'université de Paris, Paris et Besançon 1850, s. 133). Por. Ps e u do-S cot u s, Grammatica specialis, s. 27-38, 85-87. 
spekulatywnych modus significandi activus i ona stanowi podstawę podziału na te wszystkie części mowy, jakie się spotyka u Donata. Każda z tych części mowy coś oznacza, ale każda inaczej, inaczej dla właściwego sobie modus significandi activus ${ }^{8}$. Jeżeli dodamy, że według gramatyków spekulatywnych każda część mowy, obok właściwego sobie i istotnego modus significandi, spełnia nadto funkcję dodatkową, drugorzędną, modus significandi accidentalis, zależnie od fleksji, koniugacji i pozycji w zdaniu, to musimy przyznać, że przecież w średniowiecznej gramatyce zachodzą pomysły, które w dalszym ciągu mogły się okazać bardzo owocnymi, że w niej zawiera się cenny materiał dla filozofii mowy, która ogranicza się do analizy opisowej, pomijając stronę genetycznopsychologiczną języka. Już dawniej Ch. Thurot ${ }^{9}$ wskazał na niejedno złote ziarno prawdy w średniowiecznych spekulacjach filozoficznych nad gramatyką, a nawracająca do „grammaire générale et raisonnée” z w. XVII i XVIII koncepcja gramatyki uniwersalnej, jaką spotykamy u Antoniego Marty ${ }^{10}$, a jeszcze bardziej u E. Husserla ${ }^{11}$, przedstawia pewną analogię do średniowiecznej gramatyki spekulatywnej. Już średniowieczni gramatycy oddzielali zewnętrzną formę symbolów mowy od ożywiających je funkcji oznaczania, tak ogólnych jak i specjalnych, tak istotnych jak i dodatkowych, ażeby wykazać możliwość jednej wspólnej gramatyki dla wszystkich języków ${ }^{12}$.

Dyskusje filozoficzne nad gramatyką także dlatego wiążą się $\mathrm{z}$ teorią poznania, ponieważ funkcja gramatyczna, modus significandi, stosuje się do rodzaju ujęcia rzeczy przez umysł, modus intelligendi, tak jak znowu ten rodzaj ujęcia umysłowego wzoruje się na sposobie bytowania samej rzeczy, modus essendi, jako na swej normie: zachodziłby więc mniej lub więcej ścisły paralelizm między gramatycznymi modi significandi a modi intelligendi i modi essendi ${ }^{13}$.

Jak symbol słowny przez przydzielony sobie specjalny modus significandi wchodzi jako część mowy, pars orationis, w dziedzinę rozważań gramatycznych, tak znowu przez nadaną sobie funkcję zastępstwa, suppositio, wchodzi jako termin w zakres badań logiki terministycznej. Już Wilhelm Shyreswood (zm. 1249) i Lambert z Auxerre (ok. r. 1250) zredagowali niedrukowane nigdy

8 ,Cum intellectus vocum ad significandum et consignificandum imponit, duplicem ei rationem tribuit, scilicet rationem significandi, quae vocatur significatio, per quam efficitur signum [...] et rationem consignificandi, quae vocatur modus significandi activus, per quam vox significans fit consignum vel consignificans et sic formaliter est par orationis" (Pseudo-Scotus, jw., s. 8-10).

„Modus significandi activus est modus sive proprietas vocies, ab intellectu sibi concessa, mediante qua vox proprietem rei significat" (tamże, s. 7).

„Cum intellectus vocem ad significandum sub aliquo modo significandi imponit ad ipsam rei proprietatem aspicit, a qua modum significandi activum originaliter trahit" (tamże, s. 11).

9 Thurot, j.w., s. 504.

10 A. M a rt y, Untersuchungen zur Grundlegung der allgemeinen Grammatik und Sprachphilosophie, Bd. 1, Halle 1908, s. 69.

${ }^{11}$ E. H u s s e r1, Logische Untersuchungen, Bd. 2 Teil 1, Halle 1913, s. 338.

12 „Grammatica una et eadem est secundum substantiam in omnibus linquis, licet accidentaliter varietur" (Gram. graec. Ms. d'Oxford, ed. E. Charles, s. 278). Por. G. Waller and, Les oeuvres de Siger de Courtrai, Louvain 1913, s. 43.

${ }^{13}$ Pseudo-Scotus, jw., s. 11, 19. 
podręczniki do logiki terministycznej, ale wstęp do szkół zdobył dla nowego kierunku logicznego dopiero Piotr Hiszpan (zm. 1277) przez zręcznie ułożone kompedium pt. Summulae logicales ${ }^{14}$. Odtąd dzielono logikę na antiqua i moderna. Do antiqua należały: (1) logika vetus, obejmująca Isagogę Porfiriusza, Kategorie i De interpretatione Arystotelesa oraz traktaty logiczne Boecjusza; (2) Logica nova, w skład której wchodziły obydwie Analityki, księgi Topicorum i Elenchorum Stagiryty; do logica modernorum w ścisłym znaczeniu należy zaliczyć jedynie siódmy rozdział Summul logicznych Hiszpana pt. De terminorum proprietatibus, gdyż sześć pierwszych rozdziałów jest tylko streszczeniem logiki Arystotelesa, chociaż i tam występuje zabarwienie terministyczne.

Z dwóch względów zajmuje Burydan specjalne miejsce w historii logiki terministycznej: najpierw bowiem opracował nowe wydanie tekstu Piotra Hiszpana a nadto wprowadził do teorii znaków, czyli terminów, kilka zasadniczych zmian.

Wszystko, co dotychczas wiedziano o logice Burydana, opierało się na badaniach K. Prantla, który znał jedynie drukowane dzieła naszego filozofa. Przyjmowano zatem, że spod jego pióra wyszła nowa edycja tekstu Piotra Hiszpana, która później dwukrotnie ukazała się w druku wraz z komentarzem Jana Dorpa ${ }^{15}$. Tymczasem Burydan nie tylko wydał tekst Piotra Hiszpana, lecz sam napisał doń bardzo obszerną glosę, rozpoczynającą się od wyrazów „Sicut dux est salvator exercitus”, którą później Dorp zastąpił przez swoją własną. Dopiero w edycji Burydana tekst Piotra Hiszpana został istotnie podręcznikiem do nauki całej logiki, niektóre zaś zmiany w nim wprowadzone, a przede wszystkim dodany doń komentarz, miały trwale oddziałać tak na sposób pojmowania doktryny terministycznej jak nawet, w dalszej konsekwencji, na egzegezę Organonu.

Nowa redakcja tekstu zmodyfikowała do pewnego stopnia cel kompendium logicznego. Nie zauważono dotąd, że Summulae Hiszpana nie są podręcznikiem do całej logiki, lecz tylko do dialektyki w znaczeniu ścisłym. Wszak na samym wstępie Summul mamy definicję dialektyki a w dalszym ciągu rezultatom jej dociekań przyznana jest wyłącznie wartość prawdopodobieństwa ${ }^{16}$. Wiadomo, że Arystoteles wyłożył w pierwszych Analitykach teorię logiki, ażeby ją następnie zastosować do wiedzy ścisłej i pewnej - w Analitykach drugich, a w Topikach do dialektyki, której wyniki posiadają jedynie wartość 33- $\begin{array}{r}14 \\ -\end{array}$

${ }_{75}^{14}$ K. Prantl, Geschichte der Logik im Abendlande, Bd. 3, Leipzig 1867, s. 10-25, 26-32,

${ }_{15}$ Perutile compedium totius logicae Joannis Buridani cum praeclarissima sollertissimi viri Joannis Dorp expositione, Venetiis 1499; Commentum Johannis Dorp super textum Summularum Johannis Buridani nuperrime castigatum a Johanne Maioris cum aliquibus additionibus eiusdem, $\mathrm{Pa-}$ rissis 1504. Por. K. Prant 1, Geschichte der Logik im Abendlande, t. 4, Leipzig 1870, s. 14.

16 ,Dyalectica est ars arcium et sciencia scienciarum ad omnium methodorum principia viam habens" (Textus septem tractaluum Petri Hispani, Lipsiae 1520, f. A - 2 r). 
prawdopodobieństwa ${ }^{17}$. Nie zamierzał więc i Piotr Hiszpan podać całokształtu logiki w swym podręczniku, lecz chciał się ograniczyć do dialektyki, skoro na samym wstępie oświadcza, że będzie dyskutował probabiliter. Istotny cel autora występuje także wtenczas, kiedy dowodzi, że wyraz dialektyka, pochodząc

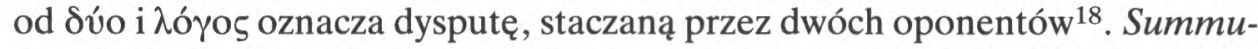
lae miały nie tyle podać zarys logiki, ile raczej przygotować umysły młodzieży do turniejów dialektycznych w czasie uniwersyteckich dysput, actus. Dodać należy, że z całego Organonu Arystotelesowego pominiętą została w Summulach najważniejsza, rdzenna jego część, drugie Analityki, rozwijające zasady

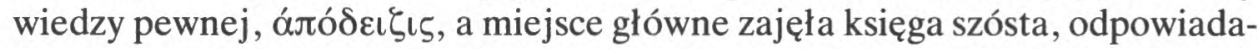
jąca Topikom, które zawierają przepisy szermierki dialektycznej ${ }^{19}$. Do tej szóstej księgi zmierza cała reszta podręcznika jako do swego celu. Jeżeli zaś po niej następuje jeszcze księga siódma o własnościach terminów, to tylko dlatego, że nie była jak wszystkie inne, wyprzedzające dialektykę, wyciągiem z jakiegoś traktatu Organonu, lecz tworem nowym, co się jeszcze najściślej wiązał $\mathrm{z}$ księgą pierwszą podręcznika, opartą na traktacie De interpretatione.

Burydan, rekonstruując tekst Piotra Hiszpana, utożsamił dialektykę z logi$\mathrm{kąq}^{20}$, ale też dlatego włączył do swego podręcznika ósmą jeszcze księgę o wiedzy ścisłej, wzorując się na drugich Analitykach Stagiryty a częściowo na De divisione Boecjusza.

Na czele swego komentarza do Summul zaznaczył Burydan, że chce objaśnić i uzupełnić tekst Piotra Hiszpana ${ }^{21}$. Aczkolwiek filozofowi z Béthune chodziło przede wszystkim o objaśnienie Summul i wszędzie Piotra Hiszpana nazywa ich autorem ${ }^{22}$, to jednak interpolacje, opuszczenia i zmiany, jakie do nich wprowadził, były wcale znaczne. Obok księgi ósmej o wiedzy ścisłej, o której wspomnieliśmy już wyżej, dodał nadto księgę dziewiątą, obejmującą w siedmiu rozdziałach 73 sofizmaty, sophismata. Sofizmaty te nie są już wyłącznie, jak dawniej w logice greckiej, wykrętnymi i błędnymi dowodami, lecz tworzą jedną z metod dydaktycznych, wykształconych przez wieki średnie ${ }^{23}$. Obok tradycyjnych paradoksów logicznych, zwanych nierozwiązalnymi lamigłówkami, insolubilia ${ }^{24}$, obok sądów wprost błędnych, impossibi-

${ }^{17}$ H. M a i e r, Die Syllogistik des Aristoteles, Teil 1, Tübingen 1896, s. V.

18 „Dicitur autem dyalectica a dya, quod est duo et logos, sermo [...] quasi duorum sermo [...] scilicet opponentis et respondentis in disputatione". (Textus septem tractatuum Petri Hispani, Lipsiae 1520 , f. A -2 r).

19 Por. Th. Gom pe r z, Griechische Denker, T. 3, Leipzig 1909, s. 39-42.

20 „Dyalectica [...] largo modo potest extendi ad totam loycam [...] et sic possumus dicere, quod hic dyalectica capitur communiter pro loyca" (Jan B u r y d a n, Compendium totius logicae, tr. I c. 1, ms BKM [= Biblioteka Zgromadzenia Księży Misjonarzy domu stradomskiego w Krakowie] 827 , f. 3 va).

21 ,Volens [...] specialiter descendere ad istum loyce tractatum brevem quem venerabilis doctor magister Petrus Hyspanus dudum composuit, exponendum et supplendum ymo aliter aliquando quam ipse dixerat et scripserat dicendum et scribendum" (Prohemium, tamże, f. 3 ra).

22 „Auctor noster”, tamże, f. $117 \mathrm{ra}, 120 \mathrm{rb}, 145 \mathrm{ra}$ itd.

23 G. Wallerand, tamże, s. 27.

${ }^{24}$ „Ego dico falsum”, Compendium totius logicae..., c. II, soph. 6,f. 187 vb. 
$l i a^{25}$, spotykamy tam zdania, które nie zaciekawiają ani swoją treścią ani formą, służąc jedynie za przykład dla zobrazowania jakiejś reguły logicznej czy gramatycznej ${ }^{26}$. Ponieważ sofizmat stał się środkiem do wytłumaczenia różnych zawiłych i niezawiłych prawideł i problemów, zachodzą raz we wszystkich księgach Summul wzmianki, że dana kwestia rozjaśni się wszechstronnie w Sofizmatach, gdzie z wykładem łączy się konkretny przykład, ujęty w szeroką sieć obiekcji i zwycięskich oczywiście rozwiązań27 ${ }^{27}$. Ważniejszym jednak od wszystkich tych interpolacji, uzupełnień, opuszczeń i korektur tekstu jest dla nas pogląd Burydana na teorię znaków, czyli terminów, która stanowi podstawę i cechę charakterystyczną całej logiki terministycznej ${ }^{28}$.

Odkąd istniała logika naukowa, tj. od czasów Arystotelesa, zajmowano się terminem jako najprostszym składnikiem sądu logicznego i sylogizmu ${ }^{29}$. Logika terministyczna badała terminy nie tylko jako części składowe sądów i sylogizmów, lecz zwróciła nadto uwagę na ich funkcję zastępstwa, suppositio. Wspomniałem już, że logika terministyczna i gramatyka spekulatywna wychodziły od wspólnego pojęcia znaku symbolicznego, ażeby je w dalszym ciągu

25 „Deus non est”, tamże, c. I, soph. 3, f. 183 vb. Sofizmat ten zachodzi już u Sigera z Brabancji: por. Ma nd on net, Siger de Brabant et l'averroisme latin au XII ${ }^{m e}$ siècle, II ${ }^{m e}$ partie, Louvain 1908, s. 73.

26 „Ego vidi Petrum et Robertum”, Compendium totius logicae, c. IV, soph. 6, f. 193 rb; „Aliquis equus non est", tamże, c. V, sph. 1, f. 200 rb. Ten rodzaj sofismatów, skonstruowanych jako przykłady dla celów wyłącznie dydaktycznych, pojawia się także u współczesnego Burydanowi Sigera z Courtrai. Nazwa ta (sofizmat) objęła już widocznie wszystkie zdania, na których wyjaśniano wyłożenie prawidla, albo od których rozpoczynano wykład. Por. G. W alle ra n d, jw., s. 28-30, gdzie jako typ sofizmatu dydaktycznego u Sigera z Courtrai występuje zdanie , amo est verbum”.

${ }^{27}$ W pierwszym na przykład traktacie ustęp o sądach modalnych kończy się słowami: „Cum tamen de eis tractabitur modicum postea [...] et amplius in tractatu de sophismatibus" (Compendium totius logicae, tr. I, c. 7, f. 13 ra).

28 Następujący, synoptyczny schemat unaoczni zmiany wprowadzone przez Burydana w układ, a częściowo i w brzmienie tekstu Piotra Hiszpana.

(A) Piotr His z p a n, Summulae, tr. I: De propositionibus (odpowiada traktatowi Arystotelesa: De interpretatione) tr. II: De praedicabilibus (Isagoga Porfiriusza), tr. III: De Praedicamentis (Kategorie Arystotelesa), tr. IV: De syllogismo (Analityki pierwsze Arystotelesa), tr. V: De locis dialecticis (Topiki Arystotelesa w przeróbce Boecjusza, PL 64, 1174-1222), tr. VI: De fallaciis (Sofizmaty Arystotelesa), tr. VII: De terminorum proprietatibus (suppositio, ampliatio, appellatio, restrictio, distributio, a nadto w późniejszych wydaniach dodatek: De exponibilibus).

(B) B u rydan, Compendium totius logicae. Rozkład materiału podał sam autor na początku glosy: „Istum librum dividendum duxi in novem tractatus, quorum primus erit de proposicionibus et de earum partibus et passionibus, secundus de predicabilibus, tercius de predicamentis,quartus de supposicionibus, quintus de syllogismo, sextus de locis dyalectis, septimus de fallaciis, octavus apponetur de divisionibus, de diffinicionibus et demonstracionibus, de quibus auctor noster in hoc libro non tractaverat, novus gerit practicam sophismatum, sed in hac lectura ego ultimum tractatum non exsequar" ( $3 \mathrm{ab}$ ). Z tego zestawienia wynika, że Burydan nie tylko przeniósł siódmą, najbardziej charakterystyczną dla terministycznej logiki księgę o zastępstwach na miejsce czwarte, wiążąc ją logicznie z traktatem o kategoriach, ale dodal nadto księgę ósmą o wiedzy ścisłej i księgę dziewiątą o sofizmatach. W księdze ósmej na czele traktatu o wiedzy ścisłej znajdują się osobne paragrafy o definicji (z Analityk drugich i Topik oraz z Piotra Hiszpana) i klasyfikacji (z Boecjusza De divisione, PL 64, 875-892); w czwartym rozdziale o sofizmatach zachodzą wzmianki z ars obligatoria, na ósmy zaś rozdział składają się insolubilia. Zmiana w układzie materiału zachodzi także w poszczególnych księgach.

${ }^{29}$ Anal. pr. I 1, 24 b 16-18. Pseudo-Scotus w Gram. spec. tak się wyraża: „Terminus dicit rationem terminandi resolutiones syllogismi in propositiones et propositiones in subiectum et praedicatum, quae dicuntur termini secundum logicum" (s. 20). 
zróżnicować na pojęcie części mowy, pars orationis, przez nadanie mu specyficznej funkcji oznaczania w pewien określony sposób, modus significandi activus, oraz na pojęcie terminu przez przydzielenie mu funkcji zastępstwa. Jak w gramatyce spekulatywnej pojęciem naczelnym, z którego jak promienie wychodziły wszystkie wywody, jest modus significandi activus, tak w logice terministycznej pojęciem centralnym jest suppositio. W jednej i drugiej nauce analiza uwzględniała zarówno stosunek znaku do oznaczanej treści i do przedmiotu jak i sam akt psychiczny, przez który głos staje się symbolem, znakiem; w jednej i drugiej nauce zachodzą zatem badania i teoriopoznawcze i psychologiczne. Ponieważ niektóre poglądy na teorię znaków i terminów Burydan podzielał $\mathrm{z}$ innymi myślicielami średniowiecznymi a nawet je presuponowal, więc też jego własne zapatrywania trzeba nieraz uzupełnić myślami ogólniejszymi, wziętymi z innych współczesnych mu lub też od niego starszych filozofów. Nie zajmuje się Burydan specjalnie gramatyką spekulatywną, ale doktryna o modi significandi jest mu dobrze znana, jak świadczą wzmianki w glosie do Summy logicznej ${ }^{30}$.

Każdy znak, tak nauczają średniowieczni gramatycy i terminiści, coś oznacza, na coś wskazuje ${ }^{31}$. Jedne znaki są naturalne, bo z natury swojej wskazują na coś poza sobą, wskazują na rzecz przez siebie oznaczaną; inne są konwencjonalne, ad placitum, gdyż funkcja oznaczania zostaje im dopiero przydzielona na podstawie specjalnego aktu psychicznego, intencjonalnego. Znaki naturalne pozostają do przedmiotu oznaczonego w stosunku realnym, znaki konwencjonalne w stosunku logicznym ${ }^{32}$. Do znaków konwencjonalnych należą symbole naszej mowy, do znaków naturalnych zalicza Szkot pojęcia ${ }^{33}$, Burydan zaś za Piotrem Hiszpanem pojęcia i głosy sygnalizujące bezpośrednio różne stany uczuciowe ${ }^{34}$.

Już Piotr Hiszpan starał się zarysować ostro różnicę między funkcją oznaczania, significatio, a zastępstwa, suppositio. Najpierw zastępstwo jest funkcją bardziej skomplikowaną, gdyż presuponuje już samą funkcję oznaczania, a dalej stosunek terminu zastępczego do przedmiotu jest inny aniżeli terminu ozna-

${ }^{30}$ Compendium totius logicae, tr. IV, c. 1 , f. 50 rab; tr. IV, c. 5, f. 69 ra.

31 „Signum dicitur respective ad aliquod signatum” (Joannes D u n s S c o t u s, Reportata, IV, d. 1 , qu. 2 , n. 3).

32 „Cum signum haec duo importat [...] scilicet fundamentum et relationem, ex hoc sequitur, quod ex parte utriusque potest distinqui. Ex parte autem relationis, quam importat signum, distinquitur signum primo in signum naturale, quod naturaliter significat et importat relationem realem ad signata; tum etiam in signum ad placitum tantum [..] quod importat relationem rationis ut sunt voces" (tamże). Por. Ps e udo-S c ot us, jw., s. 9.

33 „Passiones (seu conceptus) in quantum sunt signa et res in quantum sunt significata sunt eaedem apud omnes; nam eadem passio in anima apud quoscumque concipientes repraesentant eandem rem [...] sed voces [...] eaedem apud omnes" (J. D u n s S c o t u s, Super I Perihermeneias, qu. 4, n. 2).

${ }^{34}$ „Eedem etenim omnibus passiones anime sunt et eciam res, quarum ipse sunt similitudines” (Compendium totius logicae, tr. VII, c. 3, f. 127 ra).

"Naturaliter significat illa vox, quae apud omnes idem representat, ut gemitus infirmorum" (tamże tr. I, c. 1, f. 4 ra). Por. także: Piotr His z pa n, Summulae, tr. I, c. 1, part. 1. 
czającego: termin zastępczy bowiem stoi, jak się wyrażają komentatorowie, na miejscu przedmiotu (stare pro), wyraz zaś jako symbol słowny wskazuje jedynie na przedmiot jako na swój kres ${ }^{35}$. Trzeba dodać, że nie każdy symbol mowy może spełniać funkcję zastępstwa, choć każdy coś oznacza. Ostatni ten moment występuje u Piotra Hiszpana, choć niewyraźnie, kiedy powiada, że nadając rzeczownikowi funkcję zastępstwa, podstawiamy go za rzecz samą ${ }^{36}$. Na dwa widocznie warunki zamierzał Hiszpan przez to wskazać, mianowicie, że wyrazami zastępczymi mogą być tylko rzeczowniki a nadto, że rzeczownik musi zastępować rzecz, więc przedmiot realny a nie urojony. Ten drugi warunek bardzo energicznie podkreślił Burydan, dowodząc, że tylko wtenczas wyraz spełnia funkcję zastępstwa, kiedy na przedstawiony przezeń przedmiot można wprost wskazać jako na coś, co istnieje realnie a nie w wyobraźni jako fikcja w rodzaju potwornej chimery ${ }^{37}$. Nie wspomina natomiast Burydan o pierwszym warunku, jaki według Hiszpana musi zachodzić w terminie zastępczym, nie wspomina nigdzie o tym, że tylko rzeczownik może spełniać funkcje zastępstwa $^{38}$. Zmiana ta $\mathrm{w}$ poglądzie na suppositio pozostaje w logicznym związku z ideą, jaką wprowadził Wilhelm Ockham do logiki terministycznej. Według niego termin spełnia funkcję zastępstwa jedynie jako część składowa sądu, a nigdy poza sądem ${ }^{39}$. Nowość tę zaadoptował także Burydan ${ }^{40}$ i pod jej prawdopodobnie wpływem odstąpił od definicji Hiszpana, dopuszczającej do funkcji zastępstwa wyłącznie rzeczowniki. Wniosek był słuszny, bo jeżeli się przyjmie, że zastępstwo wiąże się z terminem, czyli z podmiotem lub orzeczeniem w sądzie, to trzeba przyznać, że funkcję te spełniają także przymiotniki czy słowa, ilekroć zachodzą w sądzie jako orzeczenie, chyba że wyrażają jaką fikcję, bo wtenczas sprzeciwiałoby się to wyżej podanej zasadzie, która głosi, że suppositio może się odnosić jedynie do przedmiotu realnego. W tym także duchu przekształcił definicję zastępstwa w swoim kompedium do logiki uczeń, a przynajmniej zwolennik Burydana, Marsyliusz z Inghen ${ }^{41}$, a polski komentator Marsyliusza, Mikołaj z Gielczewa, będzie dowodził, że z wyjątkiem synkate-

35 „Suppositio est acceptio termini iam significantis rem pro aliquo [...] Unde significatio prior est suppositione. Et secundo differunt in hoc, quia significatio est vocis, suppositio vero est termini iam compositi ex voce et significatione [...] Item tertia: significatio est signi ad signatum, suppositio vero est supponentis ad suppositum" (Petrus Hispanus, Summulae, tr. VII, part. 2, Lipsiae 1520 , f. $n-1$ r).

36 „Suppositio est acceptio termini substantivi pro aliquo" tamże, tr. VII, part. 2.

37 Compendium totius logicae, tr. IV, c. 1, f. 50 ra.

38 Warunek ten wymienia już Wilhelm Shy reswood: „Suppositio autem (est) in nomine substantivo tantum vel pronomine vel dictione substantiva ( Prantl, jw., t. 3, s. 17).

39 „Dicto de significatione terminorum restat dicere de suppositione, quae est proprietas conveniens termino, sed numquam nisi in propositione" (Summa totius logicae, I. I, c. 63). Por. Prantl, t. 3, s. 373.

${ }_{40}$ Compendium totius logicae, tr. IV, c. 1, f. 51 ra. Nadto tamże, f. 66 ra.

41 ,Suppositio est acceptio termini in propositione pro aliquo vel pro aliquibus de quo vel de quibus talis terminus verificatur mediante copula talis propositionis ut "homo currit” (Marsilius de In g h e n, Textus dialectices, Cracoviae s. a. [wyd. Florian Ungler], f. a-l). 
gorematycznych wyrażeń, jakimi są spójniki, wszystkie inne części mowy mogą być terminami zastępczymi ${ }^{42}$.

Jak z jednej strony Burydan przyjmowal niektóre nowości ockhamistyczne, ażeby przez nie uzupełnić a nawet przekształcić pogląd Hiszpana na zastępstwo, tak z drugiej strony, broniąc dotychczasowej tradycji, zwalczał inne pomysły angielskiego nowatora. Realiści XIII w. przyjmowali obok aktu poznania tzw. obraz intencjonalny przedmiotu, czyli species; species ta miała przedstawiać władzy poznawczej dany przedmiot, determinując ją w ten sposób do aktu poznania ${ }^{43}$. Ockham odrzuca wszelkie pośredniczące między aktem poznania a przedmiotem species, redukując je do samych aktów. Nie istnieją zatem odrębne pojęcia i odrębne akty psychiczne, ale same akty psychiczne są pojęciami ${ }^{44}$. Stosując nowożytną nazwę do średniowiecznej teorii, powiemy, że Ockham był psychologistą.

Burydan przeciwstawia ockhamistycznemu psychologizmowi fakt, że chociaż ustaje akt poznania, to jednak nie ginie razem $z$ nim poznana treść, ale pozostaje w duszy w pewien utajony sposób, ażeby się znów wynurzyć w świadomości przy sprzyjających okolicznościach. Nie w akcie psychicznym, lecz w species tkwi podobieństwo do poznanej rzeczy i dopiero przez species władza

42 „Sole itaque coniunctiones, cum sint pure syncategorematice, non supponunt” (Expositio magistri Nicolai Gyelczeph in passiones terminorum, Cracoviae 1507 [wyd. Jan Haller], f. a - 5). Dla odróżnienia terminów zastępczych, mogących spełniać funkcje podmiotu i orzeczenia w sądzie, podaje wprawdzie Burydan 14 reguł (zaznaczonych już u Prantla, jw., t. 3, s. 27, n. 104), lecz reguły te mimo swej drobiazgowości są niewystarczające, o ile chodzi o zastępstwo, w niektórych zaś szczegółach zdaje się ich autor nawracać do dawnego stanowiska Piotra Hiszpana, a przynajmniej przejawia się w nich dążność do transpozycji nierzeczowników na rzeczowniki (reg. 11). W związku z tym omawia podzial wyrazów na kategorematyczne i synkategorematyczne, gdyż synkategorematy nie mogą być ani podmiotem ani orzeczeniem w sądzie. Kategorematycznymi nazywają się wyrazy, które nie tylko symbolizują pojęcia, ale, poprzez pojęcia wskazują także na rzeczy przez te pojęcia oznaczone. W przeciwieństwie do nich zostają wyrazy synkategorematyczne, oznaczające pojęcia, które nie mają żadnego odpowiednika w świecie rzeczywistości. Istnieją wreszcie wyrazy, jak nikt, żaden, ktoś, które łączą w sobie własności kategorematów i synkategorematów. Różnią się nadto kategorematy od synkategorematów przez to, że pierwsze same przez się posiadają pełne znaczenie, drugie zaś muszą się łączyć z innymi wyrazami, ażeby z nimi wspóloznaczając, pelne osiągnąć znaczenie (Compendium totius logicae, tr. IV, c. 2, f. 52-53).

${ }_{43}$ G. M. Ma n se r, Drei Zweifler am Kausalprinzip im XIV Jahrhundert, , Jahrbuch für Philosophie und spekulative Teologie" 27:1912 s. 415.

44 „Dicunt aliqui quod intentiones primae et secundae sunt quaedam entia ficta (facta), quae tantum sunt obiective in mente et nullibi subiective. Contra[..] tale fictum impedit cognitionem, ergo non est ponendum propter cognitionem [...] ideo dico quod tam intentio prima quam secunda est vere actus intelligendi, quia per actum potest salvari, quidquid salvatur per fictum; eo enim, quod actus est similitudo subiecti potest significare et supponere pro rebus extra [...] ex quo patet quod intentio prima est actus intelligendi significans res, quae non sunt signa; intentio secunda est actus significans intententiones primas" (Quodlibeta, IV, qu. 19). Por. Pr a nt l, jw., t. 3, s. 338 339 , n. 768.

Niezdecydowane jeszcze było stanowisko Ockhama w Expositio aurea a nawet w komentarzu do pierwszej księgi Sentencji (por. Pr a nt l, jw., t. 3, s. 335-336), jasno już się zaznacza w Quodlibetach i w komentarzu do księgi drugiej Sentencji, qu. 14: „Si dicas, quod in visu ponitur species, dico quod non [...] nec debet poni propter praesentationem, quia in notitia intuitiva non requiritur aliquod repraesentativum vel repraesentans aliud ab obiecto et actu [...] Igitur nec in abstractiva". 
poznawcza staje się zdolna do wykonania swego wsobnego aktu ${ }^{45}$. Utożsamienie aktu z treścią, z pojęciem, wytworem (fictum) jest więc nieuzasadnione, gdyż przez to wypada w procesie poznania konieczny człon pośredni między przedmiotem i aktem poznawczym. To jedna różnica między oksfordzkim bakałarzem a jego znawcą i częściowym wyznawcą znad Sekwany. Jest i druga, bardzo poważna, choć nie tak ważna jak pierwsza. Venerabilis inceptor nauczal, że terminus, czyli symbol głosowy, może bezpośrednio wskazywać na rzeczy, a nie dopiero pośrednio poprzez pojęcia ${ }^{46}$. Burydan w swojej teorii znaków niejednokrotnie wygłasza myśl wprost przeciwną, dowodząc, że ani poszczególne wyrazy, ani całe zdania nie mają żadnego znaczenia bez ożywiających je pojęć czy sądów ${ }^{47}$.

Przez te dwa zapatrywania na samą istotę funkcji zastępstwa, sprzeciwiające się wręcz poglądom Ockhama, utrzymał się Burydan na gruncie ręalizmu, ale $\mathrm{z}$ nowatorami złączyło go ograniczenie zastępstwa do sądu wraz z wynikającymi stąd konsekwencjami. Pośrednie także stanowisko zajął nasz filozof w kwestii, która była do pewnego stopnia odgłosem dawnej kontrowersji mię-

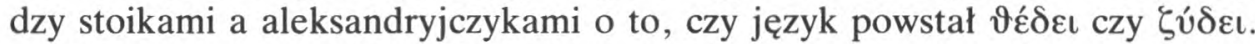
Jakkolwiek wszyscy scholastycy przyjmowali, że wyrazy są znakami konwen-

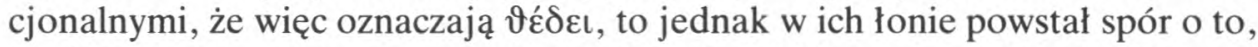
czy każdy wyraz virtute sermonis posiada stały jakiś sens, czy też może się przesuwać na inne pojęcia i z innym łączyć się znaczeniem. Kwestia ta rozpętała cały szereg zaciętych sporów między dwoma skrajnymi obozami, gdyż jedni twierdzili, że każdy wyraz ma tylko jedno, ściśle określone znaczenie, tak iż nie można mu podsuwać jakiegoś odmiennego sensu, inni zaś, rozkochani w szermierce słownej, wyzyskiwali wziętą z ars obligatoria tezę o możliwości nadawania wyrazom dowolnego znaczenia, ażeby w ten sposób udowadniać takie zuchwałe sofizmaty jak: „Ty będziesz jutro osłem”48 albo: „Nomen est trisyllabum" 49 . Pierwszy, rygorystyczny kierunek, nie dopuszczając przenośnego znaczenia w Biblii i dziełach ojców Kościoła, doprowadził do słynnej interwencji

45 „Sicut est de specie sensibili et sensatione, ita est de specie intelligibili et inteleccione, modo species sensibilis est distincta a sensacione, igitur [...] Minor probatur, quia cessante actu vel accione senciendi, species sensibiles manent in phantasia vel memoria" (Quaestiones super tres libros De anima Aristotelis, 1 . III, qu. 6, cms BJ 654, f. 137 vb).

„Species intelligibilis bene est similitudo representativa rei, sed actus intelligendi non est similitudo rei, ymo est cognoscitivus rei factus ab intellectu, disposito per huiusmodi similitudinem" (tamże f. $138 \mathrm{ra}$ ).

${ }^{46}$ L. Ku gle r, De Begriff der Erkenntnis bei Wilhelm von Ockham, Breslau 1913, s. 38-39.

47 ,Voces non significant res extra animam nisi mediantibus conceptibus, quibus subordinantur" (Compendium totius logicae, tr. I, c. 1, f. 4 vb).

„Dicciones categorematice [...] significant res aliquas mediantibus conceptibus, secundum quos conceptus vel similitudines impositi sunt ad significandum" (tamże f. 58 ra).

„Non est proposicio nisi representet proposicionem mentalem et omnis proposicio mentalis est vera vel falsa, ideo omnis proposicio mentalis representat verum vel falsum. Ideo omnis vocalis representative seu significative sumpta est vera vel falsa" (tamże f. 50va).

${ }_{48} \mathrm{U}$ Burydana pierwszy sofizmat szóstego rozdziału.

${ }^{49} \mathrm{U}$ Burydana piąty sofizmat trzeciego rozdzialu. 
uniwersytetu paryskiego w r. 1340, drugi zaś kierunek wprowadził do sal uniwersyteckich takie harce dialektyczne, jakich nie wyprawiali nawet towarzysze Euklidesa w starożytnej Megarze. Burydan nie tylko w Summie logicznej ${ }^{50}$, ale i w Sofizmatach występuje przeciw obydwu skrajnym prądom dowodząc z jednej strony, że faktycznie doktorowie uniwersyteccy i wszyscy ludzie używają wyrazów w znaczeniu przenośnym, z drugiej zaś strony wykazując, że poza dysputą, w której zgodzono się według reguł ars obligatoria na pewien odrębny sens wyrazów, należy każdy wyraz zawsze w tym znaczeniu rozumieć, jakie mu się powszechnie przypisuje w życiu codziennym ${ }^{51}$.

W całym tym sporze średniowiecznym na pozór jałowym kryje się już zawiązek idei, jaką podnosi obecnie Husserl, odgraniczając wyrazy o znaczeniu stałym i ściśle określonym od wyrazów o znaczeniu zmiennym, mętnym, ogólnikowym, które zachodzą w mowie potocznej. Husserl stara się wydzielić „idealne”, „naukowe”, „logiczne znaczenia”, jako osobną klasę, różną od całej wiecznie falującej reszty znaczeń, ażeby je zaliczyć do obszernej dziedziny przedmiotów ogólnych, allgemeine Gegenstände ${ }^{52}$. Intensywna analiza pojęć filozoficznych także w wiekach średnich doprowadziła do wyczucia potrzeby stałej i ścisłej terminologii naukowej, ale w drodze stanął fakt z psychologii zbiorowej, fakt przesuwania się znaczeń. Stąd nastąpił rozłam na dwa obozy; byli zwolennicy znaczeń stałych i zwolennicy znaczeń zmiennych. W obozie zwolenników znaczeń stałych spotkali się przypadkowo skrajni dialektycy z potępiającymi skrajność dialektyki teologami. Teologowie wskazywali na to, że i Pismo św. i ojcowie Kościoła używają wyrazów w rozmaitych znaczeniach, harcerze zaś dialektyczni przywodzili na świadectwo praktykę ze sali dysput, gdzie wstępujący w turniej dialektyczny szermierze najpierw się umawiali między sobą o sens, w jakim będą używali rozmaitych wyrażeń, ażeby snadź nie wykroczyć przeciw regułom ars obligatoria. Spór między dwoma obozami stał się groźnym dla wykładów Pisma św. na fakultecie teologicznym i dlatego też zapadła znana nam już uchwała uniwersytetu paryskiego z r. 1340 potępiająca obóz, który przez swoją tezę o znaczeniu niezmiennym i ściśle określonym wyrazów utrudniał, a nawet uniemożliwiał egzegezę Pisma św. ${ }^{53}$ Uchwała ta jednak miała dwa ostrza: jednym zwracała się przeciw zwolennikom znaczeń niezmiennych, drugim przeciw harcerzom dialektycznym, zachwaszczającym swymi subtelnościami wykład Pisma św. ${ }^{54}$ Burydan przyjmował, że de virtute

${ }^{50}$ Compendium totius logicae, tr. III, c. 3, f. $58 \mathrm{va}$.

51 Tamże, Sophismata, c. VI, soph. 1, f. 204 ra.

52 Husserl, jw., t. 2, s. 77-105.

53 „Quod nullus dicat, quod nulla propositio sit distinguenda. Qod nullus dicat propositionem nullam esse concedendam, si non sit vera in eius sensu proprio [...] quia Biblia et auctores non semper sermonibus utuntur secundum proprios sensus eorum" (H. D e nifle, A. Ch a t el a in, Chartularium Universitatis Parisiensis, t. 2, Parisiis 1891, s. 506).

${ }_{54}^{54}$ Quod nullus asserat distinctione vel expositione, quod Socrates et Plato vel Deus et creatura nihil sunt, quoniam illa verba prima facie male sonant et quia talis propositio sensum unum habet falsum, videlicet si negatio in hac distinctione „nihil” implicita intelligeretur cadere non solum su- 
sermonis mają wyrazy znaczenie stałe, lecz mimo to mogą przybierać i faktycznie nieraz przybierają znaczenie odmienne, przenośne. Dyrektywa, wyrażona w uchwale uniwersyteckiej z r. 1340, zgadza się zupełnie z zapatrywaniem Burydana, który w tym czasie był rektorem paryskiej wszechnicy i wycisnął urzędową piecząć pod dekretem fakultetu artium. Dopiero w tym oświetleniu staje się nam zupełnie zrozumiałym ten dekret, który w niektórych swych ustępach brzmi niemal identycznie z wywodami w Summie logicznej Burydana ${ }^{55}$. Zauważyliśmy już także, jak zapiski urzędowe uniwersytetu paryskiego nazywają zwolenników niezmiennych znaczeń „ockhamistami” i zarazem nadmieniają, że cios z r. 1340 przeciw nim był wymierzony. Obiektywną ocenę tych zapisek umożliwi nam dopiero pogląd na różne rodzaje zastępstwa.

Jak w samym pojęciu funkcji zastępstwa, tak i w jej podziale odstępuje Burydan zarówno od „starych” jak i od innowatora Wilhelma, a niektóre jego pomysły przejdą za pośrednictwem bardzo popularnego podręcznika Marsyliusza z Inghen na zawsze do obozu modernorum ${ }^{56}$.

Według Piotra Hiszpana i średniowiecznych realistów suppositio nazywała się personalis, kiedy wyraz zastępował takie jednostkowe przedmioty, jak Piotr, Pawel, to oto zwierzę, ten oto kamień ${ }^{57}$. W przeciwieństwie do niej zostawała suppositio simplex, bo w niej wyraz wskazywał na wspólną, gatunkową lub rodzajową rzeczywistość, jak człowiek, zwierzę lub organizm żyjący ${ }^{58}$. Przy suppositio simplex zawiązywała się zwykle dyskusja między realistami a moderni, bo „młodzi” nie przyjmowali żadnych ogółów, które by należały do świata rzeczywistości.

Ockham nie odrzucił wprawdzie zupełnie suppositio simplex, lecz nadał jej inne, aniżeli dotąd miała, znaczenie. Ogólnymi, zdaniem jego, są nie rzeczy, lecz pojęcia, a zatem, skoro przez suppositio simplex wyraz przedstawia nam ogół, może tam chodzić tylko o pojęcie a nie o rzeczy ${ }^{59}$. Zwrócił więc Ockham przez swoje odróżnianie suppositio personalis i simplex bardzo dobitnie uwagę na fakt, że myśl nasza, wychodząc od symbolu, może się posuwać w dwóch kierunkach: może się zwrócić do pojęcia i przy nim się zatrzymać jako przy ostatecznym swoim kresie, albo też może się skierować do rzeczy poza pojęciem

per ens singulariter sed et super entia pluraliter" (D e nifle, Ch a t e la in, jw., t. 2, s. 505).

55 Tamże, s. 506.

56 Pomijam tu te podziały funkçji zastępstwa, które nie przedstawiają żadnego znaczenia dla charakterystyki myśli Burydana.

57 „Personalis [...] suppositio est acceptio termini communis pro suis inferioribus, ut cum dicitur „homo currit” iste terminus „homo” supponit pro suis inferioribus” (Summulae, tr. VII, part. 3, Lipsiae 1520 , f. $n-2 v$ ).

58 „Suppositio [...] simplex est acceptio termini communis pro re universali, significata per ipsum terminum, ut cum dicitur „homo est species, animal est genus”, ibi iste terminus „homo” supponit pro homine in communi et non pro aliquo inferiori" (tamże, f. $n-2 r$ ).

59 ,Suppositio simplex est, quando terminus supponit pro intentione animae, quae aliquando est communis pluribus per praedicationem, aliquando vero est propria uni; et ratio huius est, nihil est a parte rei, quando sit simpliciter singulare. Unde error illorum, qui credebant aliquid esse in re praeter singulare et quod humanitas distincta a singularibus est aliquid in individuis et de essentia eorum" (Summa totius logicae, 1. 1, c. 66). Por. Prantl, jw., t. 3, s. 351, n. 796. 
w świecie realnym istniejącej. Ockham także zauważył, że myśl nasza, obejmując sam przystępny dla zmysłów znak, może się na nim jako na znaku zatrzymać, nie zdążając wcale do tego, co on oznacza, a więc ani do pojęcia ani do rzeczy: w tym wypadku będzie zachodziła jeszcze trzecia suppositio, tj. materialis $^{60}$.

Żeby abstrakcyjną myśl bakałarza Wilhelma ożywić i na konkretnym ją oprzeć przykładzie, powiemy, że o zwierzęciu trojakiego rodzaju możemy wypowiedzieć orzeczenia, które w trojaką nas przenoszą dziedzinę. Kiedy powiem: „Zwierzę jest wyrazem jednozgłoskowym” albo: „Zwierzę jest rzeczownikiem", wchodzę w dziedzinę gramatyki (suppositio materialis); kiedy zaś sformułuję sąd: „Zwierzę jest pojęciem gatunkowym”, wkraczam w dziedzinę logiki (suppositio simplex); wreszcie w sądzie: „Zwierzę się porusza” staję na stanowisku ontologicznym (suppositio personalis). Trzeba jednak przyznać, że Ockham nie odgraniczał konsekwentnie tych trzech rodzajów zastępstw, że terminologia jego była chwiejna ${ }^{61}$, że suppositio personalis obejmowała u niego nieraz i rzecz, i pojęcie, i wyraz.

Burydan dopiero oddzielał jasno i konsekwentnie suppositio personalis od wszelkich innych, określając ją jako zastępstwo bytów wyłącznie konkretnych, jednostkowych, a nie pojęć lub symbolów słuchowych czy wzrokowych ${ }^{62}$.

Co do suppositio simplex, to Burydan nie tylko przeczył za Ockhamem temu, jakoby przez nią terminy zastępowały jakieś rzeczywiście istniejące ogó${ }^{\prime 6}{ }^{63}$, ale nawet wykreślił samą tę nazwę ze swego słownika filozoficznego, przyjmując natomiast, że suppositio materialis obejmuje zarówno pojęcia jak i nazwy (voces) ${ }^{64}$. Różnica ta między Ockhamem a Burydanem nie jest zasadnicza, gdyż ostatecznie suppositio materialis spełnia u Burydana te same funkcje, jakie u Ockhama rozpadają się na suppositio simplex i materialis. W obozie „młodych” jedni oświadczali się za redukcją rodzajów zastępstwa, wprowadzoną przez Burydana, drudzy zostawali na dawniejszym stanowisku Ockhama. Albert ze Saksoni przyjmował suppositio simplex w interpretacji nowatora Wilhelma ${ }^{65}$, Marsyliusz z Inghen, idąc za wzorem Burydana uznawał podwójną tylko funkcję zastępstwa: suppositio materialis zmierza do symbolu, perso-

${ }^{60}$ Por. Prantl, jw., t. 3, s. 375.

${ }^{61}$ Por. Prantl, jw., t. 3, s. 374

62 "Vocatur supposicio personalis, quando vel predicatum proposicionis supponit pro suis significatis ultimatis vel pro suo ultimato significato, ut iste terminus „homo" pro hominibus in ista proposicione „homo currit” (Compendium totius logicae, tr. IV, c. 3, f. 57vb).

${ }^{63}$ Tamże, f. 58ra.

64 "Iste ergo terminus „homo" si supponat pro isto conceptu, secundum quem impositus est ad significandum homines, ut dicendo homo est universale... tunc hec vocatur supposicio materialis. Similiter si vox supponat pro seipsa vel pro simili [...] talis supposicio vocatur materialis" (tamże, f. 58rb).

65 „Suppositio simplex est [..] acceptio termini vocalis vel scripti in propositione, qui accipitur pro intentione mentis" (Logica, c. 2). Por. Prant1, t. 4, s. 66, n. 254.

"Suppositio materialis est acceptio termini, qui accipitur pro se vel pro aliquo sibi simili" ( $L o$ gica, c. 3). Por. Prantl, jw., t. 4, s. 66, n. 255. 
nalis - do rzeczy symbolizowane ${ }^{66}$. Zasadnicze znaczenie dla charakterystyki zapatrywań Burydana na ogóły posiadają myśli, jakie wypowiedział, krytykując pojęcie suppositio simplex u Piotra Hiszpana. Ogóły, dowodzi nasz filozof, nie są bytami niezależnie od naszej myśli istniejącymi, lecz są pojęciami, przez które naraz ogarniamy większą ilość przedmiotów. Przez pojęcie człowieka zwraca się nasza myśl do wszystkich ludzi jako do swego kresu, przez pojęcie zwierzęcia zwraca się do wszystkich bez wyjątku i różnicy zwierząt; same zaś pojęcia zespalają się ze symbolami językowymi „homo” i ,animal”. Zarówno więc pojęcie ogólne, jak i odpowiadające im nazwy zowią się gatunkami względnie rodzajami; jednak ta ważna zachodzi między nimi różnica, że pojęcia są gatunkami czy rodzajami same przez się, nazwy zaś albo symbole są nimi jedynie w zależności od pojęćc67.

Rozpatrzywszy różnicę zapatrywań u rozmaitych myślicieli, zajmujących się teorią terminów, możemy już tutaj w obrębie dyskusji nad logiką terministyczną postawić pytanie, czy Burydana należy zaliczyć do nominalistów, czy też do innego jakiegoś obozu. Żeby na to pytanie odpowiedzieć, musimy pojęcie nominalizmu napełnić tą treścią, jaką nam przynoszą historyczne badania nad filozofią średniowieczną. Że w średnich wiekach faktycznie istnial pewnego rodzaju nominalizm, świadczy zarówno św. Anzelm ${ }^{68}$ jak i Jan z Salisbury ${ }^{69}$ i nie można znaczenia tych świadectw osłabiać przez żadną dyskusję, wychodzącą z nowożytnej pozycji problemu ogółów. J. Reiners wykazał w gruntownym studium ${ }^{70}$, że już Boecjusz $w$ traktatach logicznych pomijał świadomie pojęcia, badając przeważnie wyrazy w ich odnośni do rzeczy. Również scholastycy IX w., wykształceni na Boecjuszu, pomijając dziedzinę pojęciową, ograniczali się do rozważania stosunku, jaki zachodzi między rzeczami (res) a wyrazami, nazwami (voces). Kiedy więc objaśniali znane już wówczas Praedicabilia Porfiriusza i Kategorie Arystotelesa, pytali się zazwyczaj, czy autorem tych dwóch dzieł chodziło o rzeczy (res) czy też o wyrazy, nazwy (voces). Tylko czę-

66 ,Suppositionem simplicem talem non pono, quamvis aliqui moderni antiquorum dicta salvare volentes dixerint, suppositionem simplicem esse, quando terminus vocalis vel scriptus stabat pro conceptu mentali [... Mihi autem non apparet huius dicti magna utilitas [...] talem terminum sic supponentem reputo supponere materialiter" (Textus dialectices, Viennae 1516, f. $161 \mathrm{v}$ ).

67 „Cum universalia secundum predicacionem principaliter dictam non sint preter animam, ita non sunt, nisi conceptus anime, quibus anima indifferenter concipit plures res, ut quia omnes homines indifferenter concipit conceptu, a quo imponitur hoc nomen homo et sic de conceptu animalis quantum ad animal. Ideo, cum species et genera sint universalia secundum predicacionem, apparet, quod species et genera sint tales conceptus anime. Verum est, quod consequenter termini vocales dicuntur genera et species, ut iste voces „homo”, , animal” - sed non dicuntur genera vel universalia principaliter, ymo secundario secundum attribucionem ad istos conceptus universales eo, quod secundum eos imposite sunt ad significandum res alias" (Compendium totius logicae, tr. IV, c. 3 , f. $58 \mathrm{ra}-\mathrm{b})$.

68 „Dialecticae haeretici, qui non nisi flatum vocis putant esse universales substantias... prorsus a spiritualium quaestionum disputatione sunt exsufflandi" (De incarnatione Verbi, PL, 158, 265).

69 „Fuerunt et qui voces ipsas genera dicerent esse et species, sed eorum iam explosa sententia est" (Polycraticus, VII, 12, PL, 199, 665).

to J. R e in ers, Der Nominalismus, s. 14. 
ścią tej ogólniejszej kwestii było pytanie, czy Porfiriusz, rozprawiając o rodzajach i gatunkach, miał na myśli symbole słowne, czy też rzeczy. Kto odpowiadał, że Porfiriuszowe gatunki były dźwiękami, voces, tego zaliczano do nominalistów, kto odpowiadał, że były rzeczami, uchodził za realistę. Nie wynika stąd, jakoby średniowieczni nominaliści wprost zaprzeczali istnieniu pojęć ogólnych, nie zaprzeczali im, lecz je pomijali, nie wprowadzając ich do dyskusji. Do tego rodzaju nominalistów należał według Reinersa ${ }^{71}$ Roscelin, bo i on twierdził, że gatunki i rodzaje są wyrazami a nie rzeczami, nie zaprzeczając przy tym wcale w sposób pozytywny istnieniu pojęć ogólnych ${ }^{72}$.

Do tego rodzaju nominalistów należy według L. Kuglera do pewnego stopnia i Ockham. Ze względu bowiem na paralelizm, zachodzący między symbolem językowym a pojęciem, uznał Ockham sam wyraz za ogół, universale, przyjmując, że nazwa w sposób bezpośredni wskazuje na rzecz przez się nazwaną, bezpośrednio, a nie dopiero za pośrednictwem pojęcia ${ }^{73}$. Powiedzieliśmy już poprzednio, że według Burydana ani całe zdanie gramatyczne ani też poszczególne jego części, wyrazy, nie wskazują same przez się i w sposób bezpośredni na żadną rzecz, lecz tylko pośrednio poprzez sąd i jego składowe części, czyli pojęcia. Jeżeli więc nominalizm średniowieczny sprowadza się do tej głównie idei, że wyrazy wskazują wprost na rzeczy, a nie dopiero za pośrednictwem pojęć, to filozofa z Béthune nie można zaliczyć do średniowiecznych nominalistów. Czy jednak poglądy Burydana nie wchodzą w ramy nominalizmu nowożytnego?

Nominalizm nowożytny występuje w podwójnej formie: sensualizmu i psychologizmu. Sensualizm wyklucza wyższy stopień poznania, psychologizm ujmuje wszelkie pojęcia tylko jako akty indywidualne, konkretne, oryginalne i wiecznie zmienne, tak iż nie mogą mieć żadnego znaczenia ogólnego ${ }^{74}$. Już z poprzednich uwag mogliśmy się przekonać, że Burydan odróżniał poznanie na stopniu zmysłowym i umysłowym, a kwestia ta wystąpi jeszcze jaśniej w dalszym ciągu pracy. Że psychologizm istniał także w wiekach średnich, mamy dowód na doktrynie Ockhama, według której pojęcia są aktami psychicznymi i niczym innym, jak tylko aktami. Nie odnajdujemy psychologizmu nominalistycznego u Burydana, gdyż w jego ujęciu pojęcia nie sprowadzają się do konkretnych aktów, lecz wyrażają w sobie podobieństwo poznanych przedmiotów; dostrzegamy :- zcze u filozofa z Béthune podstawę, co prawda niejasno występującą, do oc ióżnienia aktu psychicznego od treści, strony psychologicznej od logicznej pojęcia.

${ }^{71}$ Tamże, s. 27

72 Tamże, s. 29

${ }^{73}$ L. Kugler, jw., s. 38-39.

74 Por. krytykę nominalizmu nowożytnego u J. Ge ys e ra: Neue und alte Wege de Philosophie, Münster i. W. 1916, s. 220-237; Allegmeine Philosophie des Seins und der Natur, Münster i. W. 1915, s. 462-469; R. M. G a r rig ou - La grang e, Le sens commun. La Philosophie de l'etre et les formules dogmatiques, Paris 1901, s. 18-50; Th. G o m pe rz, Weltanschauungslehre, Bd. I, 1, Jena 1908 , s. 161. 
$\mathrm{Z}$ teorii terminów wyniknął też u Burydana ten ścisły, kategoryczny rozdział, jaki wprowadził między dziedziną logiki i metafizyki; w dalszym zaś następstwie wyniknęła, zgodna z tym rozdziałem, interpretacja Isagogi Porfiriusza i kategorii Arystotelesa. Ilekroć wyraz spełnia funkcję suppositio materialis, tylekroć wskazuje na pojęcie a nie na rzecz, kiedy zaś spełnia funkcję suppositio personalis, wskazuje poprzez pojęcia na rzecz, należącą do świata bytów realnych. Pojęciami zajmuje się logika, rzeczami metafizyka. Jeżeli tak, to należy baczyć na to, ażeby suppositio materialis ograniczyć wyłącznie do sfery logicznej, suppositio personalis wyłącznie do metafizyki, należy z kontekstu lub z ogólnego założenia autora wywnioskować, jaki w danym wypadku u niego zachodzi rodzaj zastępstwa. Ta sama nazwa substancji raz oznacza byt przez się istniejący, w niezależnym od naszej myśli świecie rzeczywistości, drugi raz pojęcie, czyli termin i tylko pojęcie tego bytu. W pierwszym wypadku wyraz, spełniając funkcję zastępstwa, zwaną suppositio personalis, wprowadza nas w dziedzinę ontologiczną, w drugim wypadku dzięki suppositio materialis w świat logiczny ${ }^{75}$.

W logicznych pismach należy stosować do wyrazów suppositio materialis a nie personalis, gdyż inaczej interpretacja będzie opaczna, błędna. Że na przykład w Kategoriach chodziło Arystotelesowi o pojęcie substancji, a nie o jego odpowiednik w świecie rzeczywistości, dowodzi fakt, że Stragiryta dzieli substancje na pierwsze, jednostkowe, i na drugie, ogólne. Na gruncie metafizyki perypatetycznej taki podział jest niewłaściwy, gdyż sprzeciwia się wprost zasadniczej myśli Arystotelesa, że wszystko, co istnieje, jest bytem jednostkowym; w logice natomiast klasyfikacja ta jest całkiem uzasadniona, bo substancjami pierwszymi będą obrazy poznawcze szczegółowe, jak Platon lub Sokrates, substancjami zaś drugimi - pojęcia, czyli terminy ogólne, jak człowiek lub zwierzę $^{76}$. Nie ulega też wątpliwości, że i Porfiriuszowi w jego Isagodze chodziło o pojęcia a nie o rzeczy; autor uważa bowiem za główny przedmiot swego traktatu praedicabile, universale, czyli to, co można orzekać, a więc pojęcia albo terminy ogólne, a nie rzeczy, przy pomocy których orzekać nie można ${ }^{77}$.

75 „Hoc nomen substacia, quantum spectat ad propositum, dicitur dupliciter. Uno modo predicatur et supponit pro pluribus per se subsistentibus et non alteri inherentibus vel eciam pro partibus huiusmodi substanciarum et sic dicimus lapides et animalia et partes eorum esse substancias et iste est principalis modus capiendi hoc nomen substacie. Sed alio modo capitur hoc nomen substancia prout supponit pro terminis de predicamento substancie" (Quaestiones super Praedicamenta Aristotelis, BJ 753, f. 86vb).

„De isto termino substancia dicendum est, quod sepe usitatur in loyca et in philosophia prout supponit pro terminis de predicamento substancie et apparet mihi, quod est supposicio materialis [...] Sed quando istud nomen substancia supponit pro rebus per se subsistentibus significatis per terminos substanciales, tunc est suppositio personalis" (Compendium totius logicae, tr. IV, c. 3, f. $59 \mathrm{ra}-\mathrm{b})$.

76 „Isto igitur secundo modo substancie dividuntur in primas et secundas et vocamus primas substancias terminos sigulares de predicamento substanciae ut Sor et Plato et vocamus secundas substancias terminos universales de predicamento substancie, ut homo, animal" (tamże, tr. 3, c. 2, f. $32 \mathrm{va}$ ). Por. BJ 753 , f. 86vb.

77 "Res [...] Hon predicantur vel subiciuntur in proposicionibus sed conceptus [...] vel termini 
Przez ten rodzaj interpretacji Kategorii Arystotelesa i Isagogi Porfiriusza łączy się Burydan częściowo i zewnętrznie raczej niż wewnętrznie z tym kierunkiem, który wychodząc od Boecjusza sięga poprzez nominalistów wczesnego średniowiecza aż do Ockhama. Pod wpływem stoików pominął Boecjusz niemal zupełnie stronę pojęciową w logice, ograniczając się do analizy skrystalizowanych w wyrazach schematów i formuł. Kiedy więc uznał, że Arystoteles nie zwracał się w Kategoriach do porządku ontologicznego, lecz zostawał w dziedzinie logiki, zadecydował, że tytuł łaciński tego dzieła winien brzmieć De vocibus a nie De rebus ${ }^{78}$. Scholastycy wczesnych wieków średnich odnieśli, według świadectwa Pseudo-Rabana, ideę Boecjusza także do Isagogi, twierdząc, że i Porfiriusz zamierzał w tym dziele mówić o nazwach, voces, a nie o rzeczach $^{79}$. Jeszcze w XIV w. głosił Ockham, że w Kategoriach Stagiryta miał na myśli wyrazy a nie rzeczy. Wprawdzie Ockham wymienił obok wyrazów pojęcia $^{80}$, lecz wiemy skądinąd ${ }^{81}$, że według niego nazwy mogą wskazywać wprost na rzeczy bez pośrednictwa pojęć. Dlatego Ockham wiąże się ściślej z omawianymi przez nas komentatorami Arystotelesa aniżeli Burydan. Burydan wychodzi nie od dźwięku, vox, lecz od obszerniejszej idei terminu, obejmującej obok symbolu głosowego także i przede wszystkim pojęcie jako znak naturalny rzeczy. Nazwa oznacza rzeczy jedynie poprzez pojęcia i stąd też Kategorie Arystotelesa oraz gatunki i rodzaje Porfiriusza są na pierwszym miejscu pojęciami, czyli terminami naturalnymi, a dopiero w zależności od pojęć znakami konwencjonalnymi, nazwami, voces.

Odgraniczył Burydan logikę od metafizyki, ale przez to samo jeszcze nie zaprzeczył wcale zachodzącego między nimi związku, bo przecież ten sam termin wskazuje zarówno na siebie jako na pojęcie lub symbol, jak i poza siebie na rzecz, wprowadzając nas raz w sferę logiki, drugi raz w sferę metafizyki. Przyjmując, że ten sam wyraz przez przydzieloną sobie suppositio materialis zastępuje pojęcie, a przez suppositio personalis rzecz, stanął Burydan w opozycji do tego skrajnego obozu, który, jak już wiemy, utrzymywał, że wszelki wyraz de virtute sermonis ma jedno tylko znaczenie. Rygorystyczna ta frakcja musiała w logice terministycznej albo przyjąć osobne wyrazy dla suppositio perso-

vocales vel scripti [...] et hec dicuntur predicabilia secundum quod innata sunt predicari de aliquibus subiectis in aliquibus proposicionibus [...] Hoc nomen predicabile proprie sumptum restringitur ad supponendum solum pro terminis communibus predicabilibus de pluribus et sic secundum hanc propriam accepcionem intendit Porphirius prius determinare de predicabilibus" (Compendium totius logicae, tr. II, c. 1, f. 22ra). Por. BJ 753, f. 85vb.

78 „Praedicamentorum tractatus non de rebus sed de vocibus est. Male igitur vel de rebus vel de rerum generibus inscripserunt" (In Categorias Aristotelis I, PL, 64, 162). Por. J. Rein e rs, jw., s. 15.

${ }^{79}$ J. Reiners, jw., s. 16.

80 „In hoc opere haec intentio est, de primis rebus nominibus et de vocibus res significantibus disputare... et ignorantia intentionis Aristotelis in hoc libro facit multos modernos errare credentes multa hic dicta pro rebus, quae tamen pro vocibus et proportionabiliter pro intentionibus seu conceptibus vult intelligi" (Expositio aurea. Prooemium). Por. F. Überweg M. B a u m gart ner, Grundriss der Geschichte der Philosophie, Zweiter Teil, Berlin 1915, s. 601.

81 Summa totius logicae, 1. I, c. 64. 
nalis i osobne dla materialis — albo też odrzucić jeden z rodzajów zastępstwa. Zdecydowano się na tezę, że wyrazy spełniają de virtute sermonis wyłącznie funkcję zastępstwa, zwanego personalis, czyli że zastępują rzeczy, a nie pojęcia.

Przeciw temu wykluczeniu suppositio materialis zwracają się znowu zgodnie ze sobą i dekret z r. $1340^{82}$ i Burydan w swoich pismach logicznych ${ }^{83}$. Jeżeli jednak księgi nacji angielskiej twierdzą, że wyrok z r. 1340 skierowany był przeciw „ockhamistom”, to trzeba zaznaczyć, że sam venerabilis inceptor takiego ciasnego poglądu nigdy nie wygłosił, a stąd wynika, że ockhamizm stał się na uniwersytecie paryskim bardzo wcześnie symbolem wszelkich błędów filozoficznych a przynajmniej tych, jakie zakwitły na gruncie logiki terministycznej. W logice tej został ślad sporu o stałe czy zmienne znaczenie wyrazów w tak zwanej alienatio, która zachodzi po raz pierwszy u Burydana ${ }^{84}$ a potem u Marsyliusza $^{85}$, oznaczając fakt przesuwania się znaczeń.

Z całej tej analizy, zostającej w obrębie logiki terministycznej, wynika, że Burydan starał się zająć stanowisko pośrednie w zasadniczej kwestii pojęć ogólnych, jak i wtenczas, kiedy „starzy” walczyli z „młodymi” o istotę zastępstwa i różne jej rodzaje, jak wreszcie wtenczas, kiedy na uniwersytecie paryskim zaognił się spór o stałość czy zmienność znaczenia wyrazów. Analiza ta nie wystarcza jednak na to, by na jej podstawie można zawyrokować, czy filozof z Béthune należał do nominalistów, czy też do innego obozu; możemy tylko już tutaj rzucić garść światla na znaczenie wyrazów „starzy” i „młodzi”, via antiqua i moderna, które tak często zachodzą u historyków filozofii, a właściwie dotąd nie zostały wcale wytłumaczone. Wiadomo, że logika dzieliła się na antiqua, obejmującą Organon Arystotelesa i na moderna, do której należą Summulae logicales Piotra Hiszpana, a szczególnie siódmy ich rozdział o terminach. Narzuca się więc od razu przypuszczenie, że antiqui byli zwolennikami logiki Arystotelesa, moderni zaś szli za mistrzem Hiszpanem. Istotnie H. Hermelink są-

82 „Quod nullus dicat simpliciter vel de virtute sermonis omnem propositionem esse falsam, quae esset falsa secundum suppositionem personalem terminorum [...] auctores enim saepe utuntur aliis suppositionibus" ( De nifle, Chat elain, jw., t. 2, s. 506).

83 „Est prima dubitacio, si terminus [...] potest supponere in aliqua proposicione materialiter et personaliter [...] hoc est dictum, ani talis proposicio „homo est species" [...] ,amo est verbum" et huiusmodi sit vera vel falsa de virtute sermonis. De hoc fuit triplex opinio. Quidam enim dixerunt istam esse falsam „homo est species” de virtute sermonis, quia principalis supposicio est personalis [...] Tercia opinio, cui ego assencio, est ista, quod vox in significando vel in supponendo non habet virtutem propriam nisi ex nobis" (Compendium totius logicae, tr. IV, c. 3, f. 58va-b). Por. Quaestiones super Isagogen Porphyrii, BJ 753, f. 87rb.

${ }^{84}$ Compendium totius logicae, tr. IV, c. 5, f. 71ra, 71vb, 72va.

${ }^{85}$ Marsyliusz w podobny sposób jak Burydan pojmuje alienatio, tj. jako przesunięcie znaczenia. Toteż Michał z Bystrzykowa podawszy definicję tej funkcji u Marsyliusza pisze: „Secundum autem rei veritatem isti gloriosi logici dicant secundum eorum figmenta, alienatio nihil aliud videtur, nisi remotio a proprio significato, ut homo mortuus: mortuus alienat hominem a sua significatione, quam habet ex sua impositione, homo pictus similiter alienat hominem a vivo homine. Et licet sic dicat Marsiliusz de alienatione, tamen alii nominales aliter dicunt" (Quaestiones magistri Michaelis Parisiensis in tractatus Parvorum logicalium Petri Hispani, Cracoviae 1507, f. 49. 
dzi, że moderni nazywali się myśliciele, którzy przez wiek XIV i XV wychodzili z podręcznika Piotra Hiszpana jako z podstawy wszelkich studiów filozoficznych ${ }^{86}$. W sądzie tym jest część prawdy i część przesady. Logika terministyczna, zawarta w podręczniku Hiszpana, była faktycznie moderna, bo jej cechę charakterystyczną stanowiło nowe, naczelne pojęcie zastępstwa, suppositio. Dlatego też Piotr Hiszpan może uchodzić za ojca wszelkich moderni. A jednak już Marsyliusz z Inghen wspomina o starych terministach i przeciwstawia im swoje modernistyczne poglądy ${ }^{87}$, a nasz Mikołaj z Gielczewa nazywa Hiszpana wprost jednym $\mathrm{z}$ najstarszych, wymieniając przy tym cały szereg moderni ${ }^{88}$. Trzeba nadto zaznaczyć, że Summulae logicales weszły jako urzędowy podręcznik także do uniwersytetów, uznających tylko via antiqua, weszły m. in. do uniwersytetu kolońskiego, a jednak nikt dlatego nie zaliczy tamtejszego tomisty, Jana Versora, do obozu modernorum; nie Summulae logicales, nawet nie parva logicalia same przez się, lecz pewien sposób ujęcia funkcji zastępstwa, suppositio, były cechą charakterystyczną młodych, do których należał także Burydan, choć nie bez zastrzeżeń. W przeciwieństwie do Piotra Hiszpana przyjmowali moderni funkcję zastępstwa jedynie w obrębie sądu i pojmowali suppositio simplex jako zastępstwo ogólnych pojęć a nie ogólnych rzeczy. Można mimo to w znaczeniu szerszym nazywać moderni tych myślicieli, którzy wszystkie dyskusje logiczne opierali na teorii terminów i w tym tylko wypadku stary Hiszpan wejdzie także do obozu młodych.

\section{UNIVERSALE NELLA FILOSOFIA DI GIOVANNI BURIDANO DAL PUNTO DI VISTA PSICOLOGICO}

\section{Riassunto}

L'articolo è un paragrafo della monografia del autore ancora non publicata. Il principale soggetto del articolo sono modi significandi e suppositio - i temi molto caratteristici nella filosofia del secolo quattodicesimo.

${ }^{86} \mathrm{H}$. He rme lin k, Die Theologische Fakultät in Tübingen vor der Reformation 1477-1534, Tübingen 1906, s. 99.

${ }_{87}$ Por. Textus dialectices, Viennae 1516, f. 161v. Marsyliusz mówi o logikach, którzy operowali pojęciem suppositio simplex, a więc należeli do terministów; prawdopodobnie miał na myśli samego Piotra Hiszpana, z którego zapatrywaniem zestawia widocznie myśl Ockhama.

88 Wymieniwszy Burydana, Jana Dorpa, Faventinusa i Piotra Tartareta kończy Mikolaj z Gielczewa uwagą: „Omnes isti auctores, qui inducti sunt, dicunt suppositionem esse de diffinitione ampliationis, sive sint moderni, ut qui sunt inducti, sive antiquissimi ut Petrus Hispanus" (Espositio magistri Nicolai Gyelczeph in passiones terminorum, Cracoviae 1507, f. $\mathrm{h}-5$ ). 